\title{
India's 2009 Elections: The Resilience of Regionalism and Ethnicity
}

Christophe Jaffrelot and Gilles Verniers

\section{(2) OpenEdition}

\section{Journals}

\section{Electronic version}

URL: http://journals.openedition.org/samaj/2787

DOI: $10.4000 /$ samaj.2787

ISSN: $1960-6060$

\section{Publisher}

Association pour la recherche sur l'Asie du Sud (ARAS)

\section{Electronic reference}

Christophe Jaffrelot and Gilles Verniers, «India's 2009 Elections: The Resilience of Regionalism and Ethnicity », South Asia Multidisciplinary Academic Journal [Online], 3 | 2009, Online since 23 December 2009, connection on 01 May 2019. URL : http://journals.openedition.org/samaj/2787 ; DOI : 10.4000/ samaj.2787

\section{(c) $($ ) $(9)$}

This work is licensed under a Creative Commons Attribution-NonCommercial-NoDerivatives 4.0 International License. 


\title{
samaj South Asia Multidisciplinary Academic Journal
}

Jaffrelot, Christophe; Verniers, Gilles 'India's 2009 Elections : The Resilience of Regionalism and Ethnicity', South Asia Multidisciplinary Academic Journal Online since 23 décembre 2009, Connection on 09 janvier 2010. URL: http://samaj.revues.org/index2787 To quote a passage, use paragraph (§).

\section{India's 2009 Elections : The Resilience of Regionalism and Ethnicity'}

Christophe Jaffrelot and Gilles Verniers

\begin{abstract}
The 2009 Indian general elections saw the Congress Party-led United Progressive Alliance retain power, with a remarkable increase of seats in the National Assembly (Lok Sabha), leading to claims of a 'renationalization' of the party system as well as of the voting pattern. However, evidence from the results themselves show that, on the contrary, the process of fragmentation of the party system and the electorate is still progressing, Indian voters having opted for regional and local players more than they ever did before. The distorting effect of the majority electoral system ('First Past The Post') provides the central explanation for this apparent paradox. A close look at the electoral results also demonstrates the resilience of 'ethnic voting', despite the recurring discourse on the predominance of 'economic voting'.
\end{abstract}


Jaffrelot, Christophe ; Verniers, Gilles 'India's 2009 Elections : The Resilience of Regionalism and Ethnicity', South Asia Multidisciplinary Academic Journal Online since 23 décembre 2009, Connection on 09 janvier 2010. URL : http://samaj.revues.org/index2787 To quote a passage, use paragraph (§).

[1] The Indian elections, which started on 13th April 2009 and ended more than one month later on May 16, broke one more record since 714 million people were eligible to vote and about $58 \%$ exercised their right to franchise ${ }^{1}$. These elections were also exceptional because of their outcome as, for the first time since 1984, the ruling party was spared the anti-incumbency reflex, which had become almost systematic till then. With 206 seats and a comfortable majority in the Lok Sabha thanks to its allies, the Congress is bound to rule for five more years with some room for manoeuvre. Indeed, the defeat of the Communists and the Bharatiya Janata Party (BJP) brings Indian politics back to the centre, the favourite political space of the Congress. Does this mean that the Congress is back to its heydays, where it had a dominating hand on the polity, and that the phase of fragmentation of Indian politics, which accelerated in the 1990s, is over? While many analysts have gone that far in a rather hasty way, a close look at the election results suggests, instead, that the fragmentation process is still progressing. This paradox can be explained partly and firstly by the distorting effect of the majoritarian electoral system, as well as by the growing propensity of various social groups to vote according to regional and ethnic identities. The 're-nationalization' of Indian politics, as opposed to the fragmentation process of the electorate and party system - characteristic of the 1990s and early 2000s - is far from being back on track, as will be developed here. This article draws essentially from a double set of quantitative data. The first set is made of the 'raw data' provided by the Election Commission of India, which we examined for some states at the constituency level. The second set originates from the National Election Study (NES) 2009, conducted by the Centre for Study of Developing Societies (CSDS). This study also provides segmented qualitative analysis that inspired, or is reflected in, some of our own analysis. Combining these data enabled us to crosscheck our own analysis while not depending entirely on the survey data.

\section{The 'Comeback' of the Congress: An Outcome of its Policies or of the Rise of Regional Parties?}

[2] Since the 1990s, India seemed to have entered into the post-Congress phase of its political history. The fate of the dominant party of yesteryears seemed to be sealed for good. It had lost its capacity to rally groups, which sometimes were poles apart, like the upper castes, the

\footnotetext{
1 The traditional cleavage between the North and the South persisted, as both displayed highly contrasted participation rates: where no Southern state registered participation rates below $63 \%$ (in Karnataka), no state of the Hindi belt exceeded $52 \%$ (in Delhi).
} 
Jaffrelot, Christophe ; Verniers, Gilles 'India's 2009 Elections : The Resilience of Regionalism and Ethnicity', South Asia Multidisciplinary Academic Journal Online since 23 décembre 2009, Connection on 09 janvier 2010. URL: http://samaj.revues.org/index2787 To quote a passage, use paragraph (§).

Dalits and the Muslims. Indeed, until the early 1990s, the Congress' dominance formula had lied upon this capacity to encompass contending social groups. It was a genuine 'catch-all party'. In the 1967 general elections for example, the vote in favour of the Congress did almost not vary according to the level of income (Madsen 1970: 100). In North India, it was more specifically based on a 'coalition of extremes' to use the terms of Paul Brass (1980: 5), since its principal supports came from the Brahmins, the Scheduled Castes and the Muslims. The party thus blurred two cleavages, the one opposing the high and the low castes, and the one separating religious communities. The same technique turned out to be successful in other regions too. The all India opinion polls conducted by the CSDS show that till the 1980s, the Congress party was able to attract between $35.8 \%$ and $50.5 \%$ of the voters from any social group ${ }^{2}$. In 1989 , the Brahmins, the Scheduled Castes, the Scheduled Tribes and the Muslims were still overrepresented within the Congress (I) electorate. According to an opinion poll survey, carried out after the 1989 elections, where the Congress (I) won $39.5 \%$ of the valid votes, it received the support of $41 \%$ of the Brahmins who were interviewed, $44.2 \%$ of the SCs/STs and $45.8 \%$ of the Muslims.

[3] But, as Table 1 shows, the 1990s witnessed an erosion of the Congress attraction amongst all sections. The BJP and a large number of regional parties were the chief beneficiaries of this decline, of this disintegration of the social coalition that sustained the party's electoral success (Chandra 2004, Chhibber 1999, Jaffrelot 2003). And if the Congress could not play the role of a catch-all party anymore, some argued that the national character of Indian politics would be at stake (Yadav 2000).

\footnotetext{
${ }^{2}$ Raw data collected at the CSDS.
} 
Jaffrelot, Christophe ; Verniers, Gilles 'India's 2009 Elections : The Resilience of Regionalism and Ethnicity', South Asia Multidisciplinary Academic Journal Online since 23 décembre 2009, Connection on 09 janvier 2010. URL: http://samaj.revues.org/index2787 To quote a passage, use paragraph (§).

Table 1: Evolution of the Congress vote (in \%) by social group (1967-1998)*

\begin{tabular}{|l|l|l|l|l|l|}
\hline $\begin{array}{l}\text { Castes } \\
\text { \& communities }\end{array}$ & \multicolumn{4}{|l|}{ Election year } \\
\hline & 1967 & 1971 & 1980 & 1996 & 1998 \\
\hline Upper castes & 41.1 & 45.6 & 35.8 & 28.4 & 28.1 \\
\hline Dominant castes & NA & NA & NA & NA & NA \\
\hline OBCs ${ }^{3}$ & 38 & 39.4 & 42 & 21.7 & 22.5 \\
\hline Scheduled Castes & 49.4 & 47.8 & 50.5 & 31.6 & 29.6 \\
\hline Scheduled Tribes & 46.2 & 41.2 & 48.6 & 39.2 & 41.9 \\
\hline
\end{tabular}

* These figures concern the Congress and its allies. Source: Surveys by the CSDS Data Unit (quoted in Mitra \& Singh 1999: 134).

[4] Yet, in 2009, the Congress performed very well in terms of seats in the Assembly, a feat even more remarkable that it was already in office since 2004. It had never won so many seats since 1991.

\section{Table 2: Congress performances (1977-2009)}

\begin{tabular}{|l|l|l|l|l|l|l|l|l|l|l|}
\hline & 1977 & 1980 & 1984 & 1989 & 1991 & 1996 & 1998 & 1999 & 2004 & 2009 \\
\hline $\begin{array}{l}\text { Number } \\
\text { of seats } \\
\text { obtained }\end{array}$ & 154 & 353 & 415 & 197 & 232 & 140 & 141 & 140 & 145 & 206 \\
\hline $\begin{array}{l}\text { Share of } \\
\text { valid } \\
\text { votes (in } \\
\% \text { ) }\end{array}$ & 34.3 & 42.7 & 48.1 & 39.5 & 36.5 & 28.80 & 25.82 & 28.30 & 26.53 & 28.5 \\
\hline $\begin{array}{l}\text { Total } \\
\text { number } \\
\text { of seats }\end{array}$ & 492 & 492 & 517 & 517 & 529 & 521 & 543 & 543 & 543 & 543 \\
\hline
\end{tabular}

\section{Source: Election Commission of India.}

[5] The Congress' 2009 election performance is remarkable for two reasons. First, no Prime Minister in office for a full term of five years had successfully fought elections since Jawaharlal Nehru in 1962. Certainly, Manmohan Singh is no Nehru. He is more of a technocrat

${ }^{3}$ The Constitutional formula, 'Other Backward Classes' (OBCs) designates the lower or intermediate castes other than the Scheduled Castes and Tribes (SCs and STs), which belong to the fourth Varna (Shudras).

${ }^{4}$ In the Lok Sabha. 
Jaffrelot, Christophe ; Verniers, Gilles 'India's 2009 Elections : The Resilience of Regionalism and Ethnicity', South Asia Multidisciplinary Academic Journal Online since 23 décembre 2009, Connection on 09 janvier 2010. URL: http://samaj.revues.org/index2787 To quote a passage, use paragraph (§).

than a statesman ${ }^{5}$. But his prestige, supported by his reputation of wisdom and integrity, is increasing among the population at large. The Congress' performance is also remarkable because of the party's score in several key states like Andhra Pradesh and Rajasthan and even more in regions where the party had been marginalized for decades. One needs to go back to 1991 (see Table 3) to see the Congress winning so many seats in Kerala (13 out of 20 - an increase of $8 \%$ in terms of valid votes compared to 2004 - against 13 in 1991) and Uttar Pradesh (21 out of 80 , an increase of $6.2 \%$ in terms of votes - even 26 out of 85 , if one includes Uttarakhand created in 2000 for making the comparison easier with the previous elections when the Congress could not win more than 16 seats over the last 20 years). In these four states, the Congress has won 45 more seats than in 2004.

Table 3: Electoral performances of the Congress in four key states

\begin{tabular}{|l|l|l|l|l|l|l|l|}
\hline States & & 1991 & 1996 & 1998 & 1999 & 2004 & 2009 \\
\hline Andhra Pradesh & Seats & & & & & & \\
& Vote share (in \%) & 45.55 & 39.66 & 38.46 & 42.79 & 41.56 & 38.95 \\
\hline Kerala & Seats & 13 & 7 & 8 & 8 & 0 & 13 \\
& Vote share (in \%) & 38.77 & 38.01 & 38.67 & 39.35 & 32.13 & 40.13 \\
\hline Rajasthan & Seats & 13 & 12 & 18 & 9 & 4 & 20 \\
& Vote share (in \%) & 43.9 & 40.51 & 44.45 & 45.12 & 41.42 & 47.19 \\
\hline Uttar Pradesh & Seats & 5 & 5 & 0 & 10 & 9 & 21 \\
& Vote share (in \%) & 18.02 & 8.14 & 6.02 & 14.72 & 12.04 & 18.25 \\
\hline
\end{tabular}

Source: Election Commission of India.

[6] Compared to 2004, the Congress has improved its results in 16 out of 28 states; a result even more striking if compared with the BJP's performances during the same period. Last but not least, the idea that Congress has benefited from a national wave - ie. from an homogeneous pattern of political following among voters across states - is also supported by its scores in terms of votes in states where it did not win many seats: in Bihar and Madhya Pradesh,

\footnotetext{
${ }^{5}$ Incidentally, he has not been elected in a popular election even once till now; he remains a Rajya Sabha member.
} 
Jaffrelot, Christophe ; Verniers, Gilles 'India's 2009 Elections : The Resilience of Regionalism and Ethnicity', South Asia Multidisciplinary Academic Journal Online since 23 décembre 2009, Connection on 09 janvier 2010. URL: http://samaj.revues.org/index2787 To quote a passage, use paragraph (§).

where total votes increased of $6.4 \%$ (the party lost one seat in the former but gained 8 in the latter), and in Punjab where they increased of $11 \%$ (with an additional 6 seats).

Table 4: State-wise performances of the Congress (INC) and the BJP (2004-09)

\begin{tabular}{|c|c|c|c|c|c|c|}
\hline & INC & - & - & BJP & $\cdot$ & - \\
\hline & 2004 & 2009 & $\begin{array}{l}\text { won/ } \\
\text { lost }\end{array}$ & 2004 & 2009 & $\begin{array}{l}\text { won/ } \\
\text { lost }\end{array}$ \\
\hline National Seats: & 145 & 206 & +61 & 138 & 116 & -22 \\
\hline Votes (\%): & 26.53 & 28.52 & +1.99 & 22.16 & 18.84 & -3.32 \\
\hline Andhra Pradesh & $\begin{array}{l}29 \\
41.56\end{array}$ & $\begin{array}{l}33 \\
38.95\end{array}$ & $\begin{array}{l}+4 \\
-2.61\end{array}$ & $\begin{array}{c}- \\
8.41\end{array}$ & $\begin{array}{c}- \\
3.75\end{array}$ & $\begin{array}{l}- \\
-4.66\end{array}$ \\
\hline Arunachal Pradesh & $\begin{array}{c}- \\
9.96\end{array}$ & $\begin{array}{l}2 \\
51.11\end{array}$ & $\begin{array}{l}+2 \\
+41.15\end{array}$ & $\begin{array}{l}2 \\
53.85\end{array}$ & $\begin{array}{c}- \\
37.17\end{array}$ & $\begin{array}{l}-2 \\
-16.68\end{array}$ \\
\hline Assam & $\begin{array}{l}9 \\
35.07\end{array}$ & $\begin{array}{l}7 \\
33.91\end{array}$ & $\begin{array}{l}-2 \\
-1.02\end{array}$ & $\begin{array}{l}2 \\
22.94\end{array}$ & $\begin{array}{l}4 \\
17.22\end{array}$ & $\begin{array}{l}+2 \\
5.82\end{array}$ \\
\hline Bihar & $\begin{array}{l}3 \\
4.49\end{array}$ & $\begin{array}{l}2 \\
10.96\end{array}$ & $\begin{array}{l}- \\
+6.43\end{array}$ & $\begin{array}{l}5 \\
14.57\end{array}$ & $\begin{array}{l}12 \\
13.93\end{array}$ & $\begin{array}{l}+7 \\
-0.64\end{array}$ \\
\hline Chandigarh & $\begin{array}{l}1 \\
52.06\end{array}$ & $\begin{array}{l}1 \\
46.87\end{array}$ & $\begin{array}{l}- \\
-5.19\end{array}$ & $\begin{array}{l}- \\
35.22\end{array}$ & $\begin{array}{l}- \\
29.71\end{array}$ & $\begin{array}{l}- \\
-5.51\end{array}$ \\
\hline Chhattisgarh & $\begin{array}{l}1 \\
40.16\end{array}$ & $\begin{array}{l}1 \\
37.31\end{array}$ & $\begin{array}{l}- \\
-3.85\end{array}$ & $\begin{array}{l}10 \\
47.78\end{array}$ & $\begin{array}{l}10 \\
45.03\end{array}$ & $\begin{array}{l}- \\
-1.75\end{array}$ \\
\hline Goa & $\begin{array}{l}1 \\
29.76\end{array}$ & $\begin{array}{l}1 \\
22.60\end{array}$ & $\begin{array}{l}- \\
-7.16\end{array}$ & $\begin{array}{l}1 \\
46.83\end{array}$ & $\begin{array}{l}1 \\
44.78\end{array}$ & $\begin{array}{l}- \\
-2.05\end{array}$ \\
\hline Gujarat & $\begin{array}{l}12 \\
43.86\end{array}$ & $\begin{array}{l}10 \\
43.38\end{array}$ & $\begin{array}{l}-2 \\
-0.48\end{array}$ & $\begin{array}{l}14 \\
47.37\end{array}$ & $\begin{array}{l}15 \\
46.52\end{array}$ & $\begin{array}{l}+1 \\
-0.85\end{array}$ \\
\hline Haryana & $\begin{array}{l}9 \\
42.13\end{array}$ & $\begin{array}{l}99 \\
41.77\end{array}$ & $\begin{array}{l}- \\
-0.46\end{array}$ & $\begin{array}{l}1 \\
17.21\end{array}$ & $\begin{array}{l}- \\
12.09\end{array}$ & $\begin{array}{l}-1 \\
-5.12\end{array}$ \\
\hline Himachal Pradesh & $\begin{array}{l}3 \\
51.89\end{array}$ & $\begin{array}{l}1 \\
45.61\end{array}$ & $\begin{array}{l}-2 \\
-6.28\end{array}$ & $\begin{array}{l}1 \\
44.24\end{array}$ & $\begin{array}{l}3 \\
49.58\end{array}$ & $\begin{array}{l}+2 \\
+5.34\end{array}$ \\
\hline Jammu and Kashmir & $\begin{array}{l}2 \\
27.83\end{array}$ & $\begin{array}{l}2 \\
24.67\end{array}$ & $\begin{array}{l}- \\
-3.16\end{array}$ & $\begin{array}{l}- \\
23.04\end{array}$ & $\begin{array}{l}- \\
18.61\end{array}$ & $\begin{array}{l}- \\
-4.43\end{array}$ \\
\hline Jharkhand & $\begin{array}{l}6 \\
21.44\end{array}$ & $\begin{array}{l}1 \\
15.02\end{array}$ & $\begin{array}{l}-5 \\
-5.42\end{array}$ & $\begin{array}{l}1 \\
33.01\end{array}$ & $\begin{array}{l}8 \\
27.53\end{array}$ & $\begin{array}{l}+7 \\
-5.48\end{array}$ \\
\hline Karnataka & $\begin{array}{l}8 \\
36.82\end{array}$ & $\begin{array}{l}6 \\
37.65\end{array}$ & $\begin{array}{l}-2 \\
+0.83\end{array}$ & $\begin{array}{l}18 \\
34.77\end{array}$ & $\begin{array}{l}19 \\
41.63\end{array}$ & $\begin{array}{l}+1 \\
+6.86\end{array}$ \\
\hline
\end{tabular}


Jaffrelot, Christophe ; Verniers, Gilles 'India's 2009 Elections : The Resilience of Regionalism and Ethnicity', South Asia Multidisciplinary Academic Journal Online since 23 décembre 2009, Connection on 09 janvier 2010. URL: http://samaj.revues.org/index2787 To quote a passage, use paragraph (§).

\begin{tabular}{|c|c|c|c|c|c|c|}
\hline Kerala & \begin{tabular}{|l|}
- \\
32.13
\end{tabular} & $\begin{array}{l}13 \\
40.13\end{array}$ & $\begin{array}{l}+13 \\
+8.00\end{array}$ & $\begin{array}{l}- \\
10.38\end{array}$ & & $\begin{array}{l}- \\
-4.07\end{array}$ \\
\hline Madhya Pradesh & \begin{tabular}{|l|}
4 \\
34.07
\end{tabular} & $\begin{array}{l}12 \\
40.44\end{array}$ & $\begin{array}{l}+8 \\
+6.37\end{array}$ & $\begin{array}{l}25 \\
48.83\end{array}$ & $\begin{array}{l}16 \\
43.45\end{array}$ & $\begin{array}{l}-9 \\
-5.38\end{array}$ \\
\hline Maharashtra & \begin{tabular}{|l|}
13 \\
23.77
\end{tabular} & $\begin{array}{l}17 \\
19.61\end{array}$ & $\begin{array}{l}+4 \\
-4.16\end{array}$ & $\begin{array}{l}13 \\
22.61\end{array}$ & $\begin{array}{l}9 \\
18.17\end{array}$ & $\begin{array}{l}-4 \\
-4.44\end{array}$ \\
\hline Manipur & \begin{tabular}{|l|}
1 \\
14.88
\end{tabular} & $\begin{array}{l}2 \\
42.96\end{array}$ & $\begin{array}{l}+1 \\
+18.08\end{array}$ & $\begin{array}{l}- \\
20.65\end{array}$ & $\begin{array}{l}- \\
9.49\end{array}$ & $\begin{array}{l}- \\
-11.16\end{array}$ \\
\hline Meghalaya & $\begin{array}{l}1 \\
45.55\end{array}$ & $\begin{array}{l}1 \\
44.84\end{array}$ & $\begin{array}{l}+1 \\
+28.08\end{array}$ & $\begin{array}{l}- \\
8.63\end{array}$ & - & - \\
\hline Mizoram & - & $\begin{array}{l}1 \\
65.58\end{array}$ & +1 & - & - & - \\
\hline Nagaland & \begin{tabular}{|l}
- \\
25.78
\end{tabular} & $\begin{array}{l}- \\
29.36\end{array}$ & $\begin{array}{l}- \\
+3.58\end{array}$ & - & - & - \\
\hline Delhi & \begin{tabular}{|l|}
6 \\
54.81
\end{tabular} & $\begin{array}{l}7 \\
57.11\end{array}$ & $\begin{array}{l}+1 \\
+2.20\end{array}$ & $\begin{array}{l}1 \\
40.67\end{array}$ & $\begin{array}{l}- \\
35.23\end{array}$ & $\begin{array}{l}-1 \\
-5.44\end{array}$ \\
\hline Orissa & $\begin{array}{l}2 \\
40.43\end{array}$ & $\begin{array}{l}6 \\
32.75\end{array}$ & $\begin{array}{l}+4 \\
-7.68\end{array}$ & $\begin{array}{l}7 \\
19.30\end{array}$ & $\begin{array}{l}- \\
16.89\end{array}$ & $\begin{array}{l}-7 \\
-2.41\end{array}$ \\
\hline Punjab & $\begin{array}{l} \\
34.17\end{array}$ & $\begin{array}{l}8 \\
45.23\end{array}$ & $\begin{array}{l}+6 \\
+11.06\end{array}$ & $\begin{array}{l}3 \\
10.48\end{array}$ & $\begin{array}{l}1 \\
10.06\end{array}$ & $\begin{array}{l}-2 \\
-0.42\end{array}$ \\
\hline Rajasthan & $\begin{array}{l}4 \\
41.42\end{array}$ & $\begin{array}{l}20 \\
47.19\end{array}$ & $\begin{array}{l}+16 \\
+5.77\end{array}$ & $\begin{array}{l}21 \\
49.01\end{array}$ & $\begin{array}{l}4 \\
36.57\end{array}$ & $\begin{array}{l}-17 \\
-12.44\end{array}$ \\
\hline Sikkim & \begin{tabular}{|l|}
- \\
27.43
\end{tabular} & $\begin{array}{l}- \\
29.59\end{array}$ & $\begin{array}{l}- \\
+2.16\end{array}$ & - & $\begin{array}{l}- \\
1.77\end{array}$ & - \\
\hline Tamil Nadu & $\begin{array}{l}10 \\
14.40\end{array}$ & $\begin{array}{l}8 \\
15.10\end{array}$ & $\begin{array}{l}-2 \\
+0.70\end{array}$ & $\begin{array}{l}- \\
5.07\end{array}$ & $\begin{array}{l}- \\
2.33\end{array}$ & $\begin{array}{l}- \\
-2.74\end{array}$ \\
\hline Tripura & $\begin{array}{l}- \\
14.28\end{array}$ & $\begin{array}{l}- \\
30.75\end{array}$ & $\begin{array}{l}- \\
+16.47\end{array}$ & $\begin{array}{l}- \\
7.82\end{array}$ & $\begin{array}{l}- \\
3.38\end{array}$ & $\begin{array}{l}- \\
-4.44\end{array}$ \\
\hline Uttar Pradesh & \begin{tabular}{|l|}
9 \\
12.04
\end{tabular} & $\begin{array}{l}21 \\
18.25\end{array}$ & $\begin{array}{l}+12 \\
+6.21\end{array}$ & $\begin{array}{l}10 \\
22.17\end{array}$ & $\begin{array}{l}10 \\
17.50\end{array}$ & $\begin{array}{l}- \\
-4.67\end{array}$ \\
\hline Uttarakhand & $\begin{array}{l}1 \\
38.31\end{array}$ & $\begin{array}{l}5 \\
43.13\end{array}$ & $\begin{array}{l}+4 \\
+4.82\end{array}$ & $\begin{array}{l}3 \\
40.98\end{array}$ & $\begin{array}{l}- \\
33.82\end{array}$ & $\begin{array}{l}-3 \\
-7.16\end{array}$ \\
\hline West Bengal & $\begin{array}{l}6 \\
14.56\end{array}$ & $\begin{array}{l}6 \\
13.45\end{array}$ & $\begin{array}{l}- \\
-1.11\end{array}$ & $\begin{array}{l}- \\
8.06\end{array}$ & $\begin{array}{l}1 \\
6.14\end{array}$ & $\begin{array}{l}+1 \\
-1.94\end{array}$ \\
\hline
\end{tabular}

Source: Election Commission of India. 
Jaffrelot, Christophe ; Verniers, Gilles 'India's 2009 Elections : The Resilience of Regionalism and Ethnicity', South Asia Multidisciplinary Academic Journal Online since 23 décembre 2009, Connection on 09 janvier 2010. URL: http://samaj.revues.org/index2787 To quote a passage, use paragraph (§).

[7] The success of the Congress is largely due to its President Sonia Gandhi whose prestige improved because of the way she gave up the trappings of executive power when she decided not to be the PM. She is very much in command of the Congress, a party which, otherwise, would be divided into many factions, as during the Narasimha Rao years (1991-96) being above factions, with the mantle of the 'dynasty' on her shoulders, she neutralizes them and maintains the cohesion of the party - and that of the United Progressive Alliance (UPA) in general, given her great talent as a negotiator and peace maker. The success of the Congress in Uttar Pradesh (UP) has been attributed to her son Rahul Gandhi, who is in charge of rebuilding the party in this former stronghold. This achievement - his first success in fact - makes him a strong contender for the post of Prime Minister after Manmohan Singh. Still, the CSDS exit poll shows that Rahul is lagging behind in terms of popularity in UP: to the question 'Who is the best personality for Chief ministership in UP?', only $4 \%$ of the respondents opted for Rahul Gandhi, against $28 \%$ for Mayawati (BSP), $27 \%$ to Mulayam Singh (SP) and $12 \%$ to Rajnath Singh (BJP) ${ }^{7}$ (Beg \& Kumar 2009: 193).

[8] The success of the Congress is also due to some of its best thought out policies, such as the National Rural Employment Guarantee Act (NREGA), which institutes a minimal guaranteed wage (amounting to one hundred days of work hours per annum, at government-fixed rates) to all rural casual workers ${ }^{8}$; the Right to Information Act, which obliges the bureaucracy to explain its decisions when asked by concerned citizens; and the implementation of a $27 \%$ quota for the OBCs in the university where, according to surveys, the Dalits were in larger number than the OBCs because of reservations ${ }^{9}$. All this pleased a popular electorate, which was also sensitive to the fall of the inflation rate: in India, a double-digit inflation can make a government

\footnotetext{
${ }^{6}$ As shown by the fact that Arjun Singh, the 'number two' in the government, then dropped his ministerial portfolio (in December 1994), particularly reproaching to Prime Minister Narasimha Rao his liberal policy that penalized the poor and his incapacity to regain the confidence of the Muslims. Shortly afterwards, he was expelled from the Congress. He founded later on the Congress (T) with N.D. Tiwari, the head of the Congress in Uttar Pradesh. Obviously, the absence of a representative of the Nehru/Gandhi lineage at the helm of the party removed the inhibitions that, till then, had restrained the appetites of factions' leaders.

${ }^{7}$ President of the Bahujan Samaj Party, Mayawati is the state's current Chief Minister. Mulayam Singh Yadav and Rajnath Singh are former Chief Ministers and respective Presidents of the Samajwadi Party and the BJP.

${ }^{8}$ According to the CSDS exit poll, $31 \%$ of the rural poor and $29 \%$ of the rural very poor said that they had benefited from the NREGA, which is more than the level of support for any other previous or existing poverty-alleviation program (Yadav \& Palshikar 2009).

${ }^{9}$ In the previous quota regime, the $27 \%$ of reservation for OBC was limited to the public service and elective assemblies. Its extension to institutions of higher education - in particular the elitist Indian Institutes of Technologies (IITs) and of Management (IIMs), as well as the public medical schools (AlIMS) stirred a violent debate between proponents of meritocracy and proponents of reservation policies.
} 
Jaffrelot, Christophe ; Verniers, Gilles 'India's 2009 Elections : The Resilience of Regionalism and Ethnicity', South Asia Multidisciplinary Academic Journal Online since 23 décembre 2009, Connection on 09 janvier 2010. URL: http://samai.revues.org/index2787 To quote a passage, use paragraph (§).

fall whereas the growth rate (on the decline since mid-2007) does not play such a big role in a country used to slow growth till the 1990s. The urban middle class also appreciated the 2008 nuclear deal with the US - through which Washington agreed to transfer civil nuclear energy technology to India in spite of the fact that the country had not signed the TNP -, not only for the mark of international recognition it represented, but also because of its implications in terms of energy.

[9] This being said, neither the success of the Congress, nor the 're-nationalization' of Indian politics that it is supposed to reflect according to the media ${ }^{10}$ must be overrated. The Congress has won 61 seats more than in 2004, but it has improved its score in terms of valid votes by only $2 \%$. In fact, the party has won approximately $27 \%$ of the valid votes in every election since 1996. The graph below shows that the two largest parties, Congress and BJP, are actually not making significant progress, whereas the regional parties are: in other words, there is no 're-nationalization' of politics in India, but a constant trend towards regionalization. As a matter of fact, regional parties got more valid votes in 2009 than the Congress and BJP combined, thus confirming a trend already visible for the first time during the 2004 elections (see Table 5).

\section{Figure 1: Vote share of the Congress, the BJP and regional parties since 1991}

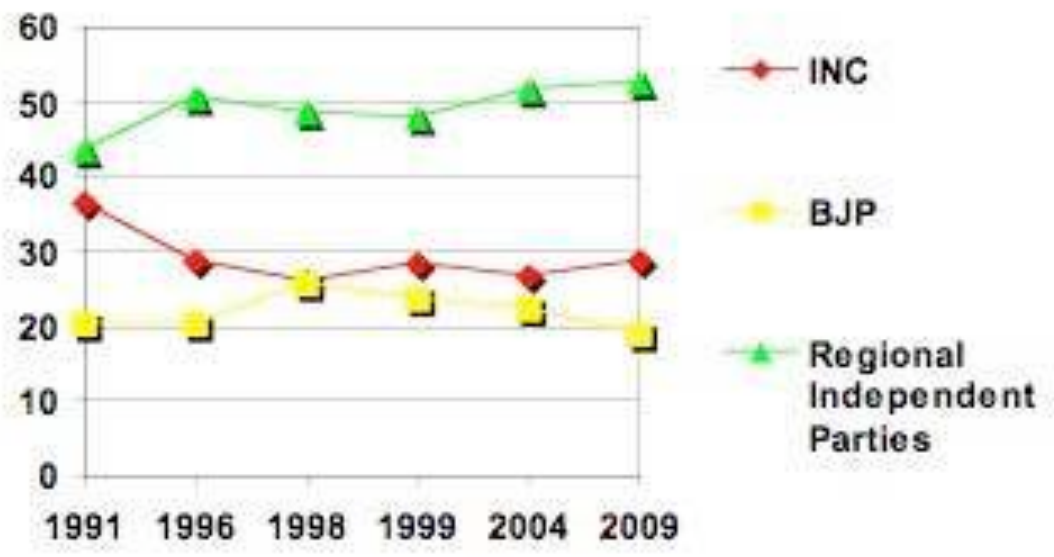

10 The press coverage of the 2009 election results was especially misleading this time - partly because of the repeated mistakes of so-called 'experts'. 
Jaffrelot, Christophe ; Verniers, Gilles 'India's 2009 Elections : The Resilience of Regionalism and Ethnicity', South Asia Multidisciplinary Academic Journal Online since 23 décembre 2009, Connection on 09 janvier 2010. URL: http://samaj.revues.org/index2787 To quote a passage, use paragraph (§).

Table 5: National and regional parties, $1991-2009$ (in \% of valid votes)*

\begin{tabular}{|l|l|l|l|l|l|l|}
\hline Parties & 1991 & 1996 & 1998 & 1999 & $\mathbf{2 0 0 4}$ & $\mathbf{2 0 0 9}$ \\
\hline Congress & 36.26 & 28.80 & 25.82 & 28.30 & 26.53 & 28.52 \\
\hline BJP & 20.11 & 20.29 & 25.59 & 23.75 & 22.16 & 18.84 \\
\hline Total & 56.37 & 49.09 & 51.41 & 52.05 & 48.59 & 47.36 \\
\hline Regional parties & 43.63 & 50.71 & 48.59 & 47.95 & 51.41 & 52.54 \\
\hline Grand Total & 100 & 100 & 100 & 100 & 100 & 100 \\
\hline
\end{tabular}

${ }^{*}$ According to the list of national parties established by the Election Commission, except for the Congress and BJP. Source: Election Commission of India.

[10] This regionalization of politics is precisely what helped the Congress, as much as the progress he made on its own. The party has benefited from this phenomenon in three distinct manners. Firstly, in many states, newly created local or regional parties - a clear indicator of the increasing fragmentation of Indian politics - have helped the Congress by denting into the votes of its main opponents, often established regional parties. In Andhra Pradesh, the Praja Rajyam Party, created by the film actor Chiranjeevi, deprived Chandrababu Naidu's Telugu Desam Partyof about 20 seats - which have mostly gone to the Congress - by winning 160000 votes per constituency on an average. In Maharashtra, the Congress and its ally, the Nationalist Congress Party won all the six seats of Mumbai thanks to the 126,000 votes that Raj Thackeray's Maharashtra Navnirman Sena (a breakaway faction of the Shiv Sena) won on an average in these constituencies - otherwise some of them at least would have been won by the Shiv Sena and/or its ally, the BJP. In Tamil Nadu, the emergence of a new party, the Dravida Munnetra Kazhagam (DMK) of Vijaykant, prevented the All India Anna Dravida Munnetra Kazagham (AIADMK) from winning in about 15 constituencies where the Congress and more especially its ally, the DMK, won most of the seats. Secondly, the Congress benefited from the good performance of its regional allies. The DMK won 18 out of 38 seats and helped the Congress to win 8. In Maharashtra, the Nationalist Congress Party (NCP), an offshoot of the Congress Party, won 9 seats. In West Bengal, the Congress re-established a very fruitful alliance with Mamata Banerjee's Trinamool National Congress (TNC) ${ }^{11}$, which won 19 seats and helped the Congress win 7 more. Thirdly, the BJP-led coalition (the National Democratic Alliance, NDA) lost very important allies prior and during the campaign.

${ }^{11}$ An offshoot of the Congress party and former ally of the BJP in the NDA coalition. 
Jaffrelot, Christophe ; Verniers, Gilles 'India's 2009 Elections : The Resilience of Regionalism and Ethnicity', South Asia Multidisciplinary Academic Journal Online since 23 décembre 2009, Connection on 09 janvier 2010. URL : http://samaj.revues.org/index2787 To quote a passage, use paragraph (§).

[11] In 2004 most of the analysts were under the impression that, indeed, it was not the Congress, which won the elections but the BJP, which lost them by using counter productive ('pro-rich') strategies and slogans such as 'Shining India'. In 2009, it seems that the Congress has hugely benefited from the crumbling down of the NDA: as a matter of fact, the departures of the Telugu Desam Party (TDP), the AIADMK, the TNC and the Biju Janata Dal (BJD) really sealed the fate of the BJP. Yogendra Yadav and Suhas Palshikar admit that 'Changes in the composition of the NDA meant a net loss of 42 seats and nearly 8 percentage points of national votes [...] if the BJP had managed to retain the NDA of 2004, the gap between the UPA and the NDA would have been much narrower' (Yadav \& Palshikar 2009: 43). One may argue that the face of the elections would have been truly changed, even because in states like Andhra Pradesh, Orissa, West Bengal and Tamil Nadu, not only would the BJP have had allies, but the Congress would have also been facing not two but one main adversary, which makes a huge difference in a 'first past the post' electoral system. Some of the former allies of the BJP - like the TNC - opted for the UPA, but others simply regained their independence and contested elections in their states on their own; another symptom of the regionalisation of politics at the expense of national coalition politics.

\section{Who Are the Real Losers?}

[12] The first real loser of the elections is the BJP. With about $19 \%$ of the valid votes, it falls below its 1991 score. It has been routed from some of its strongholds, like Delhi (no seat at all) and Rajasthan (5 out of 25 seats), and has been badly affected in others, like Uttar Pradesh (10 seats as in 2004 but with 5\% of valid votes less) and Uttarakhand (no seats, against 3 out of 5 in 2004 and 7\% votes less). The party is on a declining slope since its peak of popularity, during the 1998 general elections, where it stood at $25.59 \%$ of valid votes. Yet, the BJP has lost only $3.3 \%$ of the valid votes since 2004 and has resisted well in half a dozen states, like Himachal Pradesh ( 3 out of 4 seats), Gujarat (15 against 11 seats to Congress), Jharkhand (8 out of 11 seats) and Chhattisgarh (10 out of 11 seats) $)^{12}$. In Karnataka, its most recent conquest, the BJP has performed remarkably well with 19 out of 28 seats (with $7 \%$ votes more than in 2004). Last but not least, the BJP has doubled its score in terms of seats (4 against 2 in 2004, with 6\% votes more) in Assam thanks to its alliance with the Asom Gana Parishad. Nonetheless, in terms of

\footnotetext{
12 The BJP's support in its two Central India strongholds is however eroding. It lost respectively $5.48 \%$ and $1.75 \%$ of the votes in Jharkhand and Chhattisgarh.
} 
Jaffrelot, Christophe ; Verniers, Gilles 'India's 2009 Elections : The Resilience of Regionalism and Ethnicity', South Asia Multidisciplinary Academic Journal Online since 23 décembre 2009, Connection on 09 janvier 2010. URL: http://samaj.revues.org/index2787 To quote a passage, use paragraph (§).

vote share, the BJP loses ground in 21 states out of 28 . The 82 year old L.K. Advani, whom the BJP had projected as its prime ministerial candidate, announced his resignation from the post of leader of the opposition immediately after the elections, despite the fact that he had been asked by the Rashtriya Swayamsevak Sangh, the mother organization of the Sangh Parivar, to hold it back till the end of the year. The party is since undergoing a difficult succession process.

[13] But this is an exceptional scenario because in general the BJP found itself rather isolated. First, the NDA lost some of its members. It numbered 23 parties in 2004 but only 7 at the time of the 2009 elections. In Orissa, the BJD left the NDA just before the beginning of the campaign, depriving the BJP of an important ally - hence the local success of the Congress in terms of seats in spite of its decline in terms of votes. In Andhra Pradesh, the same scenario unfolded itself with the TDP dissociating itself and then severing its links with the BJP. Therefore, the most important question about the $15^{\text {th }}$ general elections might well be: why has the NDA shrunk so much between 2004 and 2009? One of the responses could be that the BJP seemed to be more a loser than before its 2004 defeat, but another one may well be that parties like the TDP and the BJD were not be comfortable with the Hindu nationalist discourse and practices of the Sangh Parivar. Former Andhra Pradesh Chief Minister, Chandrababu Naidu, might have come to the conclusion that the 2002 anti-Muslim pogrom in the BJP-governed state of Gujarat will dissuade Muslim voters to support its party and Navin Patnaik, current Chief Minister of Orissa, might have been indisposed by the anti-Christian activities of the Sangh Parivar in his very state. Not only did former allies abandon the BJP, but those which remained in the NDA were also not as successful as the Congress' allies. The Akali Dal has lost three seats in Punjab and the Shiv Sena one in Maharashtra. Yet, the Janata Dal (U), with 20 of 40 seats in Bihar has done very well, helping the BJP to win 9 seats.

[14] If the BJP is the biggest loser of the elections because it was plausibly expected to be back in office, the most dramatic defeat has been that of the Communists, who never won so few seats: a mere 24. Their setback is especially marked in their traditional strongholds, Kerala and West Bengal, where they won only 4 and 12 seats respectively. In Kerala, the CPI(M) paid for its internal fights and some scandals of corruption. In West Bengal, this setback is partly a sequel of Nandigram and Singur, two issues that the TNC exploited skilfully ${ }^{13}$. The defeat of the

13 Nandigram and Singur are two rural localities where peasants mobilised against the CPI(M) government's decision to let big industrialists (including Tata) build factories on a very fertile lands. The repression of the first demonstrations, which occurred in March 2007, has been especially brutal in both cases. 
Jaffrelot, Christophe ; Verniers, Gilles 'India's 2009 Elections : The Resilience of Regionalism and Ethnicity', South Asia Multidisciplinary Academic Journal Online since 23 décembre 2009, Connection on 09 janvier 2010. URL : http://samaj.revues.org/index2787 To quote a passage, use paragraph (§).

two Other Backward Classes leaders, Mulayam Singh Yadav and Laloo Prasad Yadav, who had refused to remain associated with the Congress in order to form a 'Fourth Front', is also worth mentioning. The former's Samajwadi Party saved 24 seats out of the 36 it had in UP, whereas the latter's Rashtriya Janata Dal was routed in Bihar, dropping from 23 to a measly 3 seats. In both cases, the lack of understanding with potential allies played a decisive role in their defeats.

[15] Mayawati's Bahujan Samaj Party (BSP) has been classified among the losers in most of the press reports. This is fair enough given its performances in 2007, when it had won 204 seats (a single majority) in the UP assembly, and given its expectations in 2009: it thought it would get 50 and be the kingmaker but obtained only 21 seats. But the BSP has actually made progress compared to the 2004 Lok Sabha elections (21 seats against 19) and is still, by far, the first party in terms of valid votes, $27.4 \%$ in UP 14 - 3 percentage points more than in 2004 and 10 more than the Congress. Besides, even if the BSP could win only one seat outside of UP, it won more than $5 \%$ of the votes in Punjab, Madhya Pradesh and Maharashtra and more than $15 \%$ in Haryana. The BSP, which fielded 500 candidates, has a national presence, more than any Dalit party before. As a result, and with more than $6 \%$ of the valid votes, it is now the third national party of India, ahead of the CPI(M).

\section{Towards a De-ethnicized Voting Pattern?}

[16] In India, the act of voting has always been partially over-determined by the ethnic identity of the citizen, be it based on religion, caste or language. As contentious as it may sound, the qualification 'ethnic voting' is frequently used in the academic literature as an encompassing and convenient notion regrouping the political and mobilization processes based on ascriptive identities, such as religious or caste-based groups (Chandra 2004, Chhibber 1999, Jaffrelot 2003). When more than $50 \%$ of a caste group, tribe or religious community vote for one party, we can speak of 'ethnic voting', all the more so than a rival party will nominate candidates of the same caste in order to cut into its vote. This voting pattern reflects the very structure of the party system, regionalist parties articulating a linguistic identity (like the Dravidian parties) or a religious one (like the Akali Dal for the Sikhs in Punjab or the Muslim League in Kerala). The rise of castebased parties in the 1990s has resulted in further ethnicization of electoral politics.

[17] In 2009, many observers have interpreted the rise of the Congress as a return to a national brand of politics, which entailed a certain de-ethnicization of the vote - ie. individuals from

\footnotetext{
${ }^{14}$ BSP's candidates were runner-ups in 46 constituencies of UP, sometimes losing with small margins.
} 
Jaffrelot, Christophe ; Verniers, Gilles 'India's 2009 Elections : The Resilience of Regionalism and Ethnicity', South Asia Multidisciplinary Academic Journal Online since 23 décembre 2009, Connection on 09 janvier 2010. URL: http://samaj.revues.org/index2787 To quote a passage, use paragraph (§).

all kinds of castes, tribes and communities would vote together as citizens whose political preferences are determined by an individual choice. Certainly, the Congress has attracted voters from all segments of society, but this does not mean that ethnic voting has disappeared. The BJP is similarly still associated with some sections of the electorate. According to the CSDS exit poll, almost $38 \%$ of the upper castes voted for this party - this is the only social group where the BJP is ahead of the Congress. The BJP has retained only half of its (already not many) Muslim voters: only $3.7 \%$ of them cast their vote in its favour, against $6 \%$ in 2004 . The BSP has been identified, more than ever before, with its social constituency: while the party attracted some upper caste voters in 2007 , it fell back on its Dalit base during the last elections: $21 \%$ of them voted for this party (actually more than $50 \%$ of its electorate came from this group).

Table 6: Castes, tribes and religious communities vote (in \%) in the 2009 general elections

\begin{tabular}{|l|l|l|l|l|l|l|l|}
\hline & Congress & $\begin{array}{l}\text { Congress } \\
\text { allies }\end{array}$ & BJP & $\begin{array}{l}\text { BJP } \\
\text { allies }\end{array}$ & $\begin{array}{l}\text { Communist } \\
\text { s }\end{array}$ & BSP & Others \\
\hline Upper castes & 25.5 & 6.9 & 37.9 & 5.6 & 9.0 & 3.1 & 12.1 \\
\hline Peasantcastes & 25.1 & 13.4 & 14.9 & 8.8 & 2.8 & 2.1 & 32.9 \\
\hline Upper OBC & 23.2 & 7.2 & 21.6 & 4.9 & 2.0 & 3.0 & 38.1 \\
\hline Lower OBC & 27.1 & 4.0 & 22.8 & 7.5 & 9.2 & 3.6 & 25.9 \\
\hline SC & 27.1 & 7.0 & 11.9 & 2.9 & 10.9 & 21.0 & 19.3 \\
\hline ST & 38.9 & 8.7 & 23.1 & 2.4 & 6.9 & 1.3 & 18.7 \\
\hline Muslims & 37.2 & 10.2 & 3.7 & 1.9 & 12.0 & 5.4 & 29.5 \\
\hline Others & 32.6 & 8.4 & 12.7 & 11.1 & 9.1 & 5.4 & 20.6 \\
\hline
\end{tabular}

Source: CSDS Data Unit.

[18] Ethnic voting is especially obvious at the state level given the regional dimension of castes - most of them (especially the dominant castes) do not expand beyond a linguistic area, often coterminous with one state ${ }^{15}$. A few examples will suffice to make this point. In Andhra

15 The resilience of identity politics at the state level weakens considerably the argument Yadav and Palshikar try to make: 'While caste or community continues to be the primary building bloc of political affiliation at the micro level, the politics of building a macro political coalitions based on these blocs has suffered a setback' (Yadav \& Palshikar 2009: 38). Such an assertion is puzzling since the level at which 
Jaffrelot, Christophe ; Verniers, Gilles 'India's 2009 Elections : The Resilience of Regionalism and Ethnicity', South Asia Multidisciplinary Academic Journal Online since 23 décembre 2009, Connection on 09 janvier 2010. URL : http://samaj.revues.org/index2787 To quote a passage, use paragraph (§).

Pradesh, the three most important parties continue to identify themselves with one of the three dominant castes: $65.9 \%$ of the Reddys voted for the Congress (according to the CSDS exit poll), $63.7 \%$ of the Kammas for the TDP and its allies, and $53.1 \%$ of the Kapus for the PRP (The Hindu $2009)^{16}$. In UP, $53 \%$ of the Brahmins, $53 \%$ of the Rajputs and $54 \%$ of the other upper castes voted for the BJP whereas $84 \%$ of the Jatavs ${ }^{17}$ and $64 \%$ of the other Dalits voted for the BSP (Ibid: 5). In Karnataka, $73 \%$ of the Lingayats ${ }^{18}$ voted for the BJP (Shastri, Suri et al., 2009: 117). In Rajasthan, $74 \%$ of the Brahmins, $55 \%$ of the Rajputs and $59 \%$ of the Jats voted for the BJP, whereas $66 \%$ of the Dalits, $55 \%$ of the Tribals and $82 \%$ of the Muslims voted for the Congress (Lodha 2009: 189). In some states, the electoral preferences of the voters can be better understood by looking at the sub-caste level. This fragmentation - which recalls the one we observed at the territorial level with the emergence of sub-regional parties - is especially obvious in the case of dominant castes. In Gujarat, the Patels ${ }^{19}$ need to be disaggregated that way. Two groups, the Karwa and Leuva Patels, have overwhelmingly supported the BJP - $87 \%$ of them did - during the last Lok Sabha elections (Jani 2009: 135). So far as the Muslims are concerned, 59\% of them voted for the Congress-TNC alliance in West Bengal, $77 \%$ of them supported the Congress in Delhi, 67\% in Gujarat, 68\% in Karnataka, 64\% in Madhya Pradesh, and 82\% in Rajasthan (Alam 2009: 94). Such figures do not mean that the Congress is not a catch-all party anymore - it still attracts voters from different segments -, but it does show that many groups continue to vote en bloc.

\section{Class Vote?}

[19] If caste voting remains all pervading, it is much more difficult to identify the emergence of class voting in India. In 2004, as shown in table 7, the BJP, despite its defeat, had remained the party of the middle class and the elite: the richer the Indian voter, the more he/she voted for the BJP, whereas in the case of the Congress, the correlation was the reverse.

caste has always played a key role is the state, not the locality - and certainly not the nation - and it is still the case, as evident from the CSDS data they are themselves using.

${ }^{16}$ Reddys, Kammas and Kapus are three important Shudra castes of Andhra Pradesh. Reddys and Kammas are considered dominant castes in coastal Andhra and had the upper hand on the state politics for the past three decades. Kapus located in the Telengana region have been granted the OBC status, but not in coastal Andhra.

${ }^{17}$ Former Chamars, shoemakers, who started to change their name in the late $19^{\text {th }}$ century and have become the most important Dalit caste in demographic as well as in political terms.

18 Lingayats are a group of non-Brahmin upper castes that, along with the Vokkaligas, have dominated and still dominate the Karnataka political scene.

${ }^{19}$ Patels belong to various sub-groups of the upper caste Patidars. Although fragmented, they tend to be politically and socially dominant in the state of Gujarat. 
Jaffrelot, Christophe ; Verniers, Gilles 'India's 2009 Elections : The Resilience of Regionalism and Ethnicity', South Asia Multidisciplinary Academic Journal Online since 23 décembre 2009, Connection on 09 janvier 2010. URL: http://samaj.revues.org/index2787 To quote a passage, use paragraph (§).

Table 7: Class-wise voting (in \%) in the 14th (2004) and 15th (2009) Indian general elections

\begin{tabular}{|c|c|c|c|c|c|c|c|c|c|c|c|c|c|c|}
\hline & \multicolumn{2}{|c|}{ Congress } & \multicolumn{2}{|c|}{$\begin{array}{l}\text { Congress } \\
\text { allies }\end{array}$} & \multicolumn{2}{|l|}{ BJP } & \multicolumn{2}{|c|}{ BJP allies } & \multicolumn{2}{|l|}{ Left } & \multicolumn{2}{|l|}{ BSP } & \multicolumn{2}{|c|}{ Others } \\
\hline & 2004 & 09 & 2004 & 09 & 2004 & 09 & 2004 & 09 & 2004 & 09 & 2004 & 09 & 2004 & 09 \\
\hline $\begin{array}{l}\text { Upper } \\
\text { Class }\end{array}$ & 25.4 & 30.3 & 5.8 & 7.3 & 30.3 & 24.5 & 12.4 & 6.5 & 7.8 & 3.8 & 3.1 & 4.6 & 15.1 & 22.9 \\
\hline $\begin{array}{l}\text { Middle } \\
\text { Class }\end{array}$ & 29.9 & 29.3 & 8.7 & 7.6 & 28.9 & 18.5 & 12.6 & 5.3 & 7.0 & 6.1 & 1.8 & 4.5 & 11.12 & 28.7 \\
\hline $\begin{array}{l}\text { Lower } \\
\text { Middle } \\
\text { Class }\end{array}$ & 26.0 & 28.8 & 10.7 & 5.4 & 22.1 & 19.7 & 13.6 & 4.5 & 7.4 & 6.4 & 4.1 & 7.0 & 16.0 & 28.2 \\
\hline Poor & 24.8 & 27.3 & 10.6 & 8.3 & 20.3 & 16.8 & 13.8 & 4.4 & 7.5 & $\begin{array}{l}10 . \\
6\end{array}$ & 7.0 & 8.7 & 16.1 & 23.9 \\
\hline Very Poor & 27.0 & 27.1 & 11.4 & 10.0 & 18.0 & 16.2 & 14.5 & 6.1 & 9.4 & $\begin{array}{l}11 . \\
3\end{array}$ & 7.4 & 7.9 & 12.3 & 21.4 \\
\hline Total & 26.4 & 28.6 & 10.1 & 7.8 & 22.2 & 18.8 & 13.7 & 5.3 & 8.0 & 7.6 & 5.3 & 6.2 & 14.3 & 25.7 \\
\hline
\end{tabular}

\section{Source : CSDS Data Unit.}

[20] In 2009, this type of linear relation no longer held good for the rural milieu - the one that matters the most ${ }^{20}$. Here, the rich voted as much as the poor for the Congress and - one of the striking aspects of these elections - the BJP was no longer the party of the well-heeled, whether urban or rural, who voted like the poor for the Congress. The latter succeeded on both fronts: on the one hand, Manmohan Singh's economic policies, based on balanced liberalization measures, drew the wealthy urban milieus. On the other hand, the flagship social schemes identified moreover with Sonia Gandhi - was a magnet for the poorer rural milieus.

${ }^{20}$ According to the CSDS' NES, the rural electorate represents $71.8 \%$ of the total electorate. 
Jaffrelot, Christophe ; Verniers, Gilles 'India's 2009 Elections : The Resilience of Regionalism and Ethnicity', South Asia Multidisciplinary Academic Journal Online since 23 décembre 2009, Connection on 09 janvier 2010. URL: http://samaj.revues.org/index2787 To quote a passage, use paragraph (§).

Table 8: Class-wise and urban/rural-wise voting (in \%) in the 15th (2009) Indian general elections

\begin{tabular}{|c|c|c|c|c|c|c|c|c|}
\hline & Congress & $\begin{array}{l}\text { Congress } \\
\text { allies }\end{array}$ & BJP & $\begin{array}{l}\text { BJP } \\
\text { allies }\end{array}$ & Left & BSP & $4^{\text {th }}$ front & Others \\
\hline \multicolumn{9}{|l|}{ Rural } \\
\hline Up. Cl. & 30.1 & 5.5 & 23.1 & 7.8 & 4.2 & 4.9 & 8.4 & 15.9 \\
\hline Middle $\mathrm{Cl}$. & 29.9 & 9.4 & 19.0 & 5.7 & 7.0 & 4.1 & 3.6 & 24.8 \\
\hline LowerMid.Cl. & 28.6 & 4.4 & 20.3 & 3.9 & 6.2 & 7.3 & 7.3 & 22.1 \\
\hline Poor & 27.3 & 6.8 & 17.7 & 4.4 & 10.2 & 8.9 & 6.2 & 18.5 \\
\hline Very Poor & 26.6 & 8.3 & 17.0 & 6.0 & 12.1 & 8.3 & 7.9 & 13.8 \\
\hline Total & 28.4 & 6.3 & 18.9 & 5.4 & 8.4 & 6.7 & 6.3 & 19.6 \\
\hline \multicolumn{9}{|l|}{ Urban } \\
\hline Up. Cl. & 30.5 & 9.6 & 26.3 & 4.8 & 3.3 & 4.3 & 2.4 & 18.8 \\
\hline Middle Cl. & 28.4 & 9.9 & 17.6 & 4.6 & 5.0 & 5.0 & 2.1 & 27.0 \\
\hline LowerMid.Cl. & 29.8 & 10.8 & 16.8 & 7.2 & 7.2 & 5.8 & 3.8 & 18.6 \\
\hline Poor & 27.5 & 17.8 & 11.1 & 4.8 & 12.7 & 7.2 & 2.5 & 16.3 \\
\hline Very Poor & 30.5 & 22.4 & 11.1 & 6.9 & 5.5 & 4.7 & 3.2 & 15.7 \\
\hline Total & 29.1 & 11.6 & 18.5 & 5.1 & 5.5 & 5.1 & 2.4 & 22.8 \\
\hline
\end{tabular}

\section{Source: CSDS Data Unit.}

[21] This trend does not prevent the BJP from remaining an urban-based party, as the voters' desertion was more pronounced among the poor in the rural rather than urban areas. One linear relation that persists is education: the CSDS survey reveals that the more educated the Indian voter, the more likely he or she is to vote for the BJP. But this, again, has more to do with caste than class.

\section{Conclusion}

[22] The 2009 Indian general elections have not been the turning point that most commentators had predicted ${ }^{21}$. The Congress' success neither translated into a real renationalization of the party system nor into a de-ethnicizing of the vote. Certainly, the Congress has done much better in many states where it was pitched against the BJP in straight fights, but

21 'The voters appeared to have delivered a decisive verdict, one that heralded a new era in the country's politics' stated The Hindu in its special elections supplement (The Hindu 2009). Other such misinterpretations could be found elsewhere as well. 
Jaffrelot, Christophe ; Verniers, Gilles 'India's 2009 Elections : The Resilience of Regionalism and Ethnicity', South Asia Multidisciplinary Academic Journal Online since 23 décembre 2009, Connection on 09 janvier 2010. URL : http://samaj.revues.org/index2787 To quote a passage, use paragraph (§).

otherwise, its performance in terms of seats does not reflect its real popularity. This optical illusion stems firstly from the single-round majoritarian voting system, which meant that the growing fragmentation of the regional political scenes, particularly in the case of triangular or quadrangular competitions, has acted in favour of the Congress, the most consistent though not dominant player.

[23] The distortion between vote-shares and results in terms of seats - due to the voting system - is not a new phenomenon in India, where the electoral fate of parties always depends more on their adversaries' performances than on their own. Even if the Congress has often obtained a majority of seats in the Lok Sabha, sometimes with a considerable margin, it has never obtained more than $48 \%$ of the vote share (in 1984). On the contrary, between the 1999 defeat and the 2004 victory, the Congress' vote share had decreased by $2 \%$ (Shastri, Suri et al. 2009: 4). Yet, this distortion was certainly more striking in 2009, due to the increased fragmentation of the political scene. The Congress thus won seats in three states in which it lost vote share (Andhra Pradesh, Maharashtra and Orissa). The same applies to the BJP in Gujarat, Jharkhand and Bihar incidentally. One may add in this respect that the multiplication of triangular - and sometimes quadrangular - competitions rendered any attempt at predicting the electoral outcome completely illusory.

[24 The other conclusion we can draw from our study is that these elections demonstrate once again that the regional level is the most determining one. In the CSDS post-poll National Election survey, $70 \%$ of those interviewed considered loyalty to their region to be more important than loyalty to the nation; only $14 \%$ of those interviewed thought otherwise (The Hindu 2009). The Indian general elections continue to be the aggregate of 28 regional elections, each displaying its social, political and economic specificities. In such a context, regional parties will continue to rise. With a total of $52.54 \%$ vote share, against $47.36 \%$ for the Congress and BJP clubbed together, regional parties attract an absolute majority of voters. This trend has been on a continuous rise since 1999. Not only are regional parties progressing but they are also multiplying, and the most important among them fail to become 'meta-regional', to take root in neighbouring states. Even if the BSP managed to penetrate in Haryana for instance, and garner a few votes in some subregional pockets (Vidharba, notably), these elections confirm the fact that regional parties remain confined to the states from which they originate. The vote share of the so-called 'multi-state' parties has been on a constant decline since 1999 , falling from $20.11 \%$ to $16.24 \%$ of the votes. In sum, the fragmentation of the political scene confirms India's entry into the 'coalition era'. As 
Jaffrelot, Christophe ; Verniers, Gilles 'India's 2009 Elections : The Resilience of Regionalism and Ethnicity', South Asia Multidisciplinary Academic Journal Online since 23 décembre 2009, Connection on 09 janvier 2010. URL : http://samai.revues.org/index2787 To quote a passage, use paragraph (§).

always, post-poll negotiations have been tense, the formation and survival of the Government depending on the goodwill of regional - even local - players.

Figure 2: Vote share of Congress, the BJP, multi-state parties and, regional parties since 1991

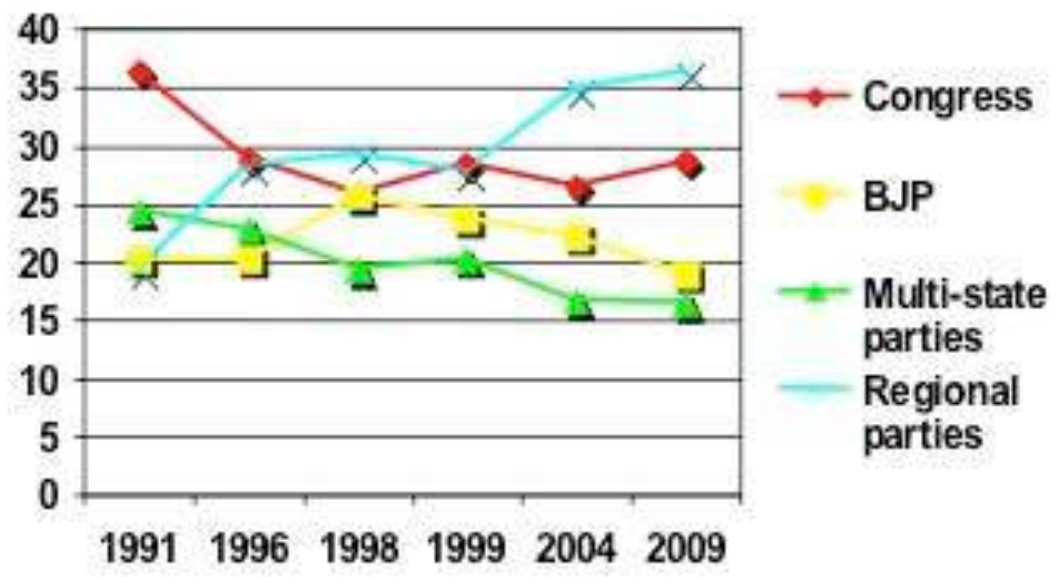

[25] With 262 seats, the UPA coalition achieved a near absolute majority at the Lok Sabha. It had no trouble finding the necessary additional seats to ensure the stability of its Government, picking and choosing amongst the 'Third' and 'Fourth Fronts'. The Congress managed to gather practically all the so-called secular parties, with the exception of the Left. What kind of policies will this coalition government implement? It is particularly difficult to draw a lesson from these elections in terms of the mandate given to the government. Of course, the propoor redistributive policies of the Congress contributed to its electoral success and it is understood that the electorate expects the party to follow the same direction. But it is equally interesting to point out what the voters did not say. These elections, for instance, cannot be interpreted as a call for the pursuit of liberalization and deregulation policies. This is borne out in the Congress' loss in vote share in all economically advanced states (Gujarat, Maharashtra, Karnataka). Nonetheless, these liberalization, even privatization, policies will continue at a pace dependent on Manmohan Singh's ability to convince its most reluctant partners - the DMK and the TNC - but also Sonia Gandhi herself, that it would be the best development strategy to follow in a period of economic slowdown. 
Jaffrelot, Christophe ; Verniers, Gilles 'India's 2009 Elections : The Resilience of Regionalism and Ethnicity', South Asia Multidisciplinary Academic Journal Online since 23 décembre 2009, Connection on 09 janvier 2010. URL: http://samaj.revues.org/index2787 To quote a passage, use paragraph (§).

\section{References}

Alam, Mohamed Sanjeer (2009) 'Whither Muslim Politics', Economic \& Political Weekly, 44, pp. 92-95.

Beg, Mirza Asmer; Kumar Suhil (2009) 'Uttar Pradesh: Signs of a Congress Revival?', Economic \& Political Weekly, 44, pp. 190-193.

Brass, Paul (1980) 'The Politicization of the Peasantry in a North Indian State - Part II', Journal of Peasant Studies, 8, pp. 3-36.

Chandra, Kanchan (2004) Why Ethnic Parties Succeed: Patronage and Ethnic Head Counts in India, Cambridge \& New York: Cambridge University Press.

Chhibber, Pradeep K. (1999) Democracy without Associations: Transformation of the Party System and Social Cleavages in India, Ann Arbor: University of Michigan Press.

Economics \& Political Weekly, 2009. 'National Election Study 2009', 44 (39).

Jaffrelot, Christophe (2003) India's Silent Revolution: The Rise of the Lower Castes in North India, New York: Columbia University Press.

Jani, Mahashweta (2009) 'Gujarat: BJP Scrapes Through', Economic \& Political Weekly, 44, pp. 133-136.

Lodha, Sanjay (2009) 'Rajasthan: Performance and Campaigning Pay Dividends', Economic \& Political Weekly, 44, pp. 186-190.

Madsen, Douglas (1970) 'Solid Congress Support in 1967: A Statistical Inquiry', Asian Survey, Special Issue 'Elections and Party Politics in India: A Symposium', 10 (11), pp. 1004-1014.

Mitra, Subrata K.; Singh, V. B. (1999) Democracy and Social Change in India: A Cross-Sectional Analysis of the National Electorate, New Delhi \& Thousand Oaks: Sage Publications.

Shastri, Sandeep; Devi, Veena \& Padmavathi, B. S. (2009) 'Karnataka: A Default Win for the BJP', Economic \& Political Weekly, 44, pp. 114-117.

Shastri, Sandeep; Suri, K. C. \& Yadav, Yogendra (eds.) (2009) Electoral Politics in Indian States: Lok Sabha Elections in 2004 and Beyond, New Delhi: Oxford University Press.

The Hindu, 2009. 'How India Voted', 26 May.

Yadav, Yogendra (2000) 'Understanding the Second Democratic Upsurge: Trends of Bahujan Participation in Electoral Politics in the 1990s', in Francine R. Frankel, Zoya Hasan, Rajeev Bhargava \& Balveer Arora (eds.), Transforming India: Social and Political Dynamics of Democracy Delhi: Oxford University Press, pp. 120-145.

Yadav, Yogendra; Palshikar, Suhas (2009) 'Between Fortuna and Virtu: Explaining the Congress' Ambiguous Victory in 2009', Economic \& Political Weekly, 44, pp. 33-46. 